\title{
Summary
}

\section{SENSITIVITY OF STREPTOCOCCUS PLURANIMALIUM CLINICAL ISOLATE TO ANTISEPTICS}

Faustova M.O.

Key words: S. pluranimalium, antiseptic, chlorhexidine, decasan, chlorophyllipt

Recent reports have stressed out a global increase in the identification of new pathogens, which are not characteristic for the human microbiota, as well as significant changes in the microbial composition of different biotopes of its body. The purpose of this study was to investigate the sensitivity of S. pluranimalium clinical isolate to antiseptics. Materials and methods. The clinical isolate of S. pluranimalium was taken from the patient's mouth. The isolation and cultivation of the microorganism was carried out by standard techniques. Final identification was performed using an automatic bacteriological analyzer. The sensitivity of the studied S. pluranimalium isolate to antiseptics was determined by the method of double serial dilutions in liquid nutrient medium, in accordance with the Order №167 of the Ministry of Public Health of Ukraine on "On Approval of Training Guidance" Assessment of the sensitivity of microorganisms to antibiotics". The sensitivity was assessed by the minimum inhibitory and minimum bactericidal concentrations in $\mu \mathrm{g} / \mathrm{ml}$. The sensitivity of the clinical isolate under the study was determined to $0.05 \%$ for chlorhexidine, $0.05 \%$ for decasan, and $2.0 \%$ for chlorophyllipt extract. According to the results obtained, the clinical isolate of S. pluranimalium was sensitive to the action of antiseptics in varying degrees. The antiseptics of the Quaternary ammonium compound group had a more pronounced antimicrobial effect on the test organism compared to the chlorophyllipt extract. Conclusions. Among these antiseptics, the tested strain of streptococcus was the most sensitive to decasan, compared with chlorhexidine and natural extract of chlorophyllipt, the minimum inhibitory and minimum bactericidal concentrations of which exceeded these indicators of decasan.

DOI 10.31718/2077-1096.20.2.185

УДК 616.65-006

Мед В.В., Бабенко В.І., Филенко Б.М.

ДЕЯКІ МОРФОЛОГІЧНІ ПРОГНОСТИЧНІ КРИТЕРІЇ РАКУ ПЕРЕДМІХУРОВОЇ ЗАЛОЗИ

Українська медична стоматологічна академія, м. Полтава

Найбільш розповсюдженою гістологічною фрормою раку передміхурової залози є ацинарна аденокарцинома різного ступеня диференціювання. Основним діагностичним критерієм, що враховується при виборі методу лікування раку передміхурової залози, є морфологічний атипізм залоз, який відображається у шкалі Гліссона, а також ступінь експресії імуногістохімічних маркерів, одним з яких $є$ альфра-метилацил-КоА-рацемаза. Проте, залишається не повністю зрозумілою залежність вираженості експресії p504S від ступеня градації пухлини за системою Гліссона. Метою дослідження було встановлення взаємозв язку між ступенем диференціювання аденокарциноми передміхурової залози за шкалою Гліссона та ступенем експресії ІГХ маркеру p504s. Було досліджено біопсійний матеріал, отриманий від 37 пацієнтів з раком передміхурової залози. За шкалою Гліссона матеріал розподілили на три групи: перша відповідала оцінці 1-4 бали, друга - 5-7 балів та третя - 8-10 балів. ІГХ дослідження з визначення експресії антигену p504s проводили за допомогою моноклональнux анти-AMACR/P504s. Аналіз залежності між ступенем дифреренціювання аденокарциноми передміхурової залози за шкалою Гліссона та ступенем експресії ІГХ маркеру р504s, було виявлено чітку закономірність та встановлено наявність сильного кореляційного зв'язку $(r=0,69)$ між даними морфологічними характеристиками пухлини. Виявлена нами закономірність при виконанні дослідження говорить про специфічність даного маркеру при злоякісних пухлинних процесах у передміхуровій залозі, що узгоджується з даними інших досліджень, та дає змогу більш точно дифреренціювати стадійність процесу за шкалою Гліссона. Це певною мірою дає підгрунтя для вибору адекватних методів лікування пацієнтів та удосконалити прогностичні критерії.

Ключові слова: рак передміхурової залози, атипізм, шкала Гліссона, AMACR, прогноз.

Робота є фррагментом НДР: «Закономірності морфогенезу органів, тканин та нервово-судинних утворів у нормі, при патології та під впливом екзогенних чинників», № державної реєстрації $0118 U 004457$.

\section{Вступ}

За даними ВООЗ рак передміхурової залози (РПЗ) займає 4 місце серед злоякісних пухлин у чоловіків, а смертність від карциноми даної локалізації посідає 2 місце. В Україні спостерігається тенденція до постійного зростання захворюваності на рак передміхурової залози. За даними Національного Канцер Реєстру, відзначається в середньому 40 випадків смерті на сто тисяч населення у рік [1]. Захворюваність на РПЗ зростає з віком пацієнта, а пік припадає на 70 років.

Найбільш розповсюдженою гістологічною формою РПЗ є ацинарна аденокарцинома різного ступеня диференціювання [2, 3]. Основним діагностичним критерієм, що враховується при виборі методу лікування раку передміхурової залози, є морфологічний атипізм залоз, який ві- 
дображається у шкалі Гліссона, а також ступінь експресії імуногістохімічних маркерів, одним 3 яких $\epsilon$ альфа-метилацил-КоА-рацемаза (AMACR/p504S) [4, 5]. Числове значення ступеня диференціювання пухлини за шкалою Гліссона $€$ важливим прогностичним критерієм, що дозволяє припустити більш швидке прогресування захворювання, метастазування і зниження виживання. Маркер AMACR, в свою чергу, експресується у 80-100\% випадках аденокарциноми передміхурової залози та дозволяє диференціювати рак від інших патологічних процесів $[6,7]$. Проте, залишається не повністю зрозумілою залежність вираженості експресії p504S від ступеня градації пухлини за системою Гліссона.

Метою дослідження було встановлення взаємозв язку між ступенем диференціювання аденокарциноми передміхурової залози за шкалою Гліссона та ступенем експресії ІГX маркеру p504s.

\section{Матеріали та методи}

Було досліджено біопсійний матеріал отриманий від 37 пацієнтів з раком передміхурової залози. Вік чоловіків коливався від 49 до 80 років, та в середньому становив $67,1 \pm 6,9$ років. Препарати готувалися шляхом фіксування шматочків біопсійного матеріалу в $10 \%$ розчині формаліну, їх зневоднення в спиртах висхідної концентрації та заливки в парафінові блоки. Отримані зрізи фарбували гематоксиліном і еозином за загальноприйнятою методикою $[8,9]$.

За шкалою Гліссона матеріал розподілили на три групи: перша відповідала оцінці 1-4 бали, друга - 5-7 балів та третя - 8-10 балів.

ІГХ дослідження з визначення експресії антигену p504s проводили за допомогою моноклональних анти-AMACR/P504s антитіл клону 13H4 («Dako-cytomation»). Імуногістохімічне дослідження проводили на зрізах парафінових блоків товщиною 4 мкм, фріксованих 10\% формаліном, відповідно до рекомендацій Dako-cytomation 3 використанням біотинімунопероксидази та наступним забарвленням гематоксиліном Майєра $[10,11]$.

Позитивна реакція для AMACR визначалася при дифузному або зернистому цитоплазматичному забарвленні клітин. Відсоткова позитивність оцінювалась від 0 до 3+ таким чином: 0\% клітин з експресією - негативна експресія (0+), 1\%-10\% клітин - слабка (1+), 11\%-50\% клітин помірна (2+) та $>51 \%$ забарвлених клітин - виражена експресія (3+) [12].

При мікроскопічному дослідженні використовували мікроскоп Olympus BX-41 з набором ліцензійних програм з фотозйомкою на цифрову фотокамеру фрірми «Olympus C 4040».

Для статистичного аналізу застосовували методи непараметричної статистики (для визначення відмінностей груп - U-критерій Манна Уітні), та метод рангової кореляції Спірмена (r) для виявлення взаємозв язку у групах. Достовірність статистичної значущості відмінностей та достовірність кореляційних зв`язків приймалась при $p<0,05$. Статистична обробка даних проводилась за допомогою програми Microsoft Excel та Jamovi 1.1.9. [13].

\section{Результати дослідження та їх обговорення}

Для визначення ступеня морфологічної атипії залоз використовували наступні критерії: оцінці 1-4 бали (I група) відповідав матеріал з тісно прилягаючими або дещо розрізненими, переважно мономорфними ацинусами, з невеликими проміжками строми між ними, присутність кубічного та циліндричного епітелію залоз та відсутністю клітин базального шару (Рис. 1А).

При наявності більшого різноманіття будови ацинусів з формуванням витягнутих і розгалужених структур, варіантів їх розміру від дрібних до відносно великих, та, в деяких випадках, при формуванні сосочкових, криброзно-сосочкових або солідно-залозистих структур, присутності темноклітинної епітеліальної вистилки та явного інфільтративного росту - матеріал оцінювали в 5-7 балів (II група) (Рис. 1B).
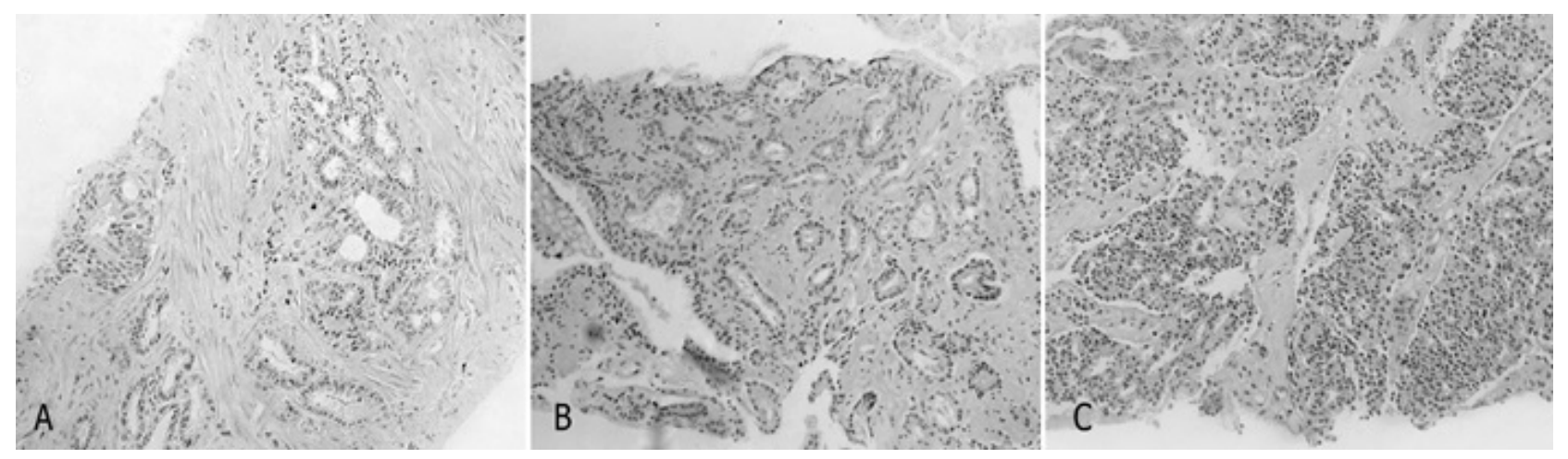

Рис. 1. А) матеріал РПМ з I групи, який відповідає оцінці 2+2 бали

за Гліссоном; В) матеріал з II групи, який відповідає оцінці 3+3 бали за Гліссоном; C) матеріал РПМ з III групи, який відповідає оцінці 5+4 бали за Гліссоном. Забарвлення гематоксиліном і еозином. Збільшення ×100. 


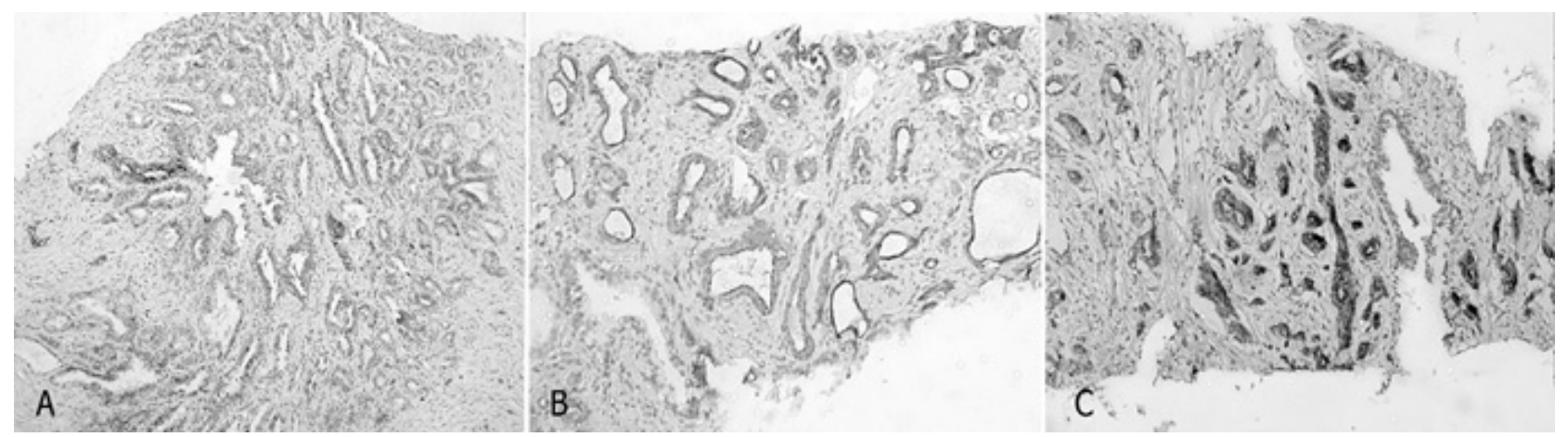

Puc. 2. A) мікропрепарат PПЗ зі слабким ступенем експресії AMACR; B) мікропрепарат РПЗ з помірним ступенем експресії AMACR; C) мікропрепарат PПЗ з вираженою експресією AMACR. IГХ забарвлення. Збільшення ×100.

8-10 балам (III група) відповідав матеріал з характерним великовогнищевим зливним ростом невеликих ацинусів з формуванням дрібних солідно-залозистих комплексів з незначними просвітами, зливного криброзного росту залозистих структур, варіантів гландулоцитів з «гіпернефроїдноподібною» цитоплазмою, а також при наявності ізольованих великовогнищевих солідно-залозистих та криброзних комплексів ракової паренхіми з некротизованими масами у просвіті ацинусів, або дифузного росту дрібних низькодиференційованих "спотворених» залоз (Рис. 1C) $[6,14]$.

Таким чином, при досліджені біопсійного матеріалу, в групу, яка відповідає оцінці 1-4 бали за шкалою Гліссона (І група) увійшло 5 випадків РПЗ; в групу, що відповідає 5-7 балам (II група) 23 випадки та в групу, яка відповідає 8-10 балам (III група) - 9 випадків.
При імуногістохімічному дослідженні з маркером AMACR виявили, що в I групі 80\% препаратів РПЗ (4 випадки) мали слабкий ступінь експресії (Рис. 2A) та 20\% препаратів були негативно забарвленими. В II групі 21,73\% (5 випадків) спостерігався слабкий ступінь експресії, 69,56\% (16 випадків) - помірний ступень експресії (мал. 2B) та 8,69\% (2 випадки) - інтенсивна експресія (мал. 2C). В III групі 22,22\% (2 випадки) виявлений помірний ступінь експресії та $77,77 \%$ (7 випадків) - інтенсивна експресія маркеру p504s.

Провівши аналіз залежності між ступенем диференціювання аденокарциноми передміхурової залози за шкалою Гліссона та ступенем експресії ІГХ маркеру p504s, було виявлено чітку закономірність та встановлено наявність сильного кореляційного зв'язку $(r=0,69)$ між даними морфологічними характеристиками пухлини (діаграма 1).

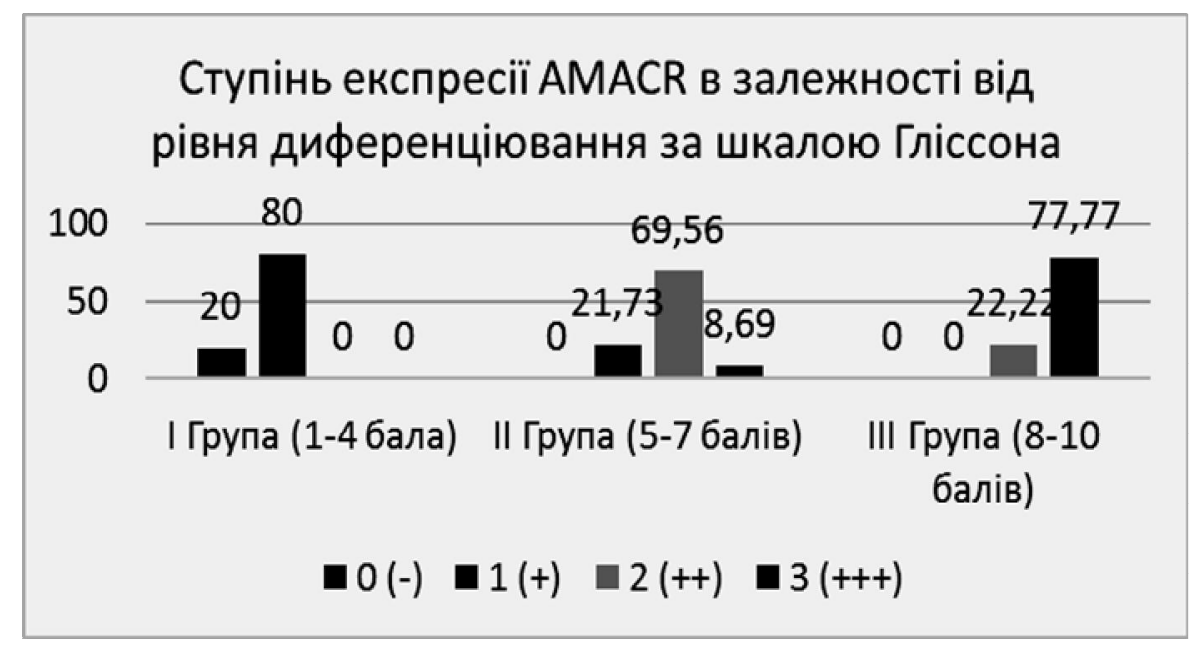

Діаграма 1. Залежність ступеня диферениіювання аденокарциноми

передміхурової залози за шкалою Гліссона та ступенем експресії IГX маркеру р504s.

За літературними даними AMACR $є$ специфрічним геном для раку передміхурової залози, що кодує білок, який приймає участь в бетаокисленні жирних кислот. Експресія білку AMACR виявляється в аденокарциномі передміхурової залози, але не визначається при доброякісних захворюваннях простати. Отже, моноклональні антитіла для виявлення AMACR мають важливе значення для діагностики AMACR- позитивних варіантів раку [15]. Проте, за даними деяких дослідників, використання лише AMACR в якості позитивного маркера може вводити в оману, оскільки слабка експресія даного маркера може також спостерігатися при деяких передракових процесах та захворюваннях в передміхуровій залозі. Тому, вони рекомендують використання AMACR в якості позитивного маркера поряд 3 визначенням експресії базально- 
клітинного специфічного антигену, HMWCK (34ßE12) та Р63. Це підвищує діагностичну точність при аденокарциномі передміхурової залози і зменшить ймовірність помилкового діагнозу [16].

Виявлена нами закономірність при виконанні дослідження вказує на специфічність даного маркеру при злоякісних пухлинних процесах у передміхуровій залозі, що узгоджується з даними інших досліджень $[3,4,7]$, та дає змогу більш точно диференціювати стадійність процесу за шкалою Гліссона. Це, певною мірою, дає підґрунтя для вибору адекватних методів лікування пацієнтів та удосконалення прогностичних критеріїв.

\section{Висновки}

Золотим стандартом при дослідженні раку передміхурової залози залишається визначення ступеня морфологічної атипії залоз за шкалою Гліссона. AMACR $є$ специфічним геном для раку передміхурової залози, використання якого у поєднанні з патогістологічними характеристиками підвищить діагностичну точність. Комбінація патогістологічного дослідження та визначення рівня експресії AMACR може бути додатковим критерієм прогнозу для раку передміхурової залози.

Перспективним $€$ дослідження паренхіматозно-стромальних зв'язків при раку передміхурової залози з вивченням ролі рак-асоційованих фібробластів.

\section{Література}

1. Kolesnik OO redaktor Biuleten Natsionalnoho kantser-reiestru "Rak v Ukraini, 2017-2018" [National Cancer Registry Bulletin "Rak v Ukraini, 2017-2018" Cancer in Ukraine, 2017-2018]
raku; 2019. 101 s. (Ukrainian).

2. Krutenko OV. Patohistolohichni ta imunohistokhimichni osoblyvosti raku peredmikhurovoi zalozy [Pathohistological and immunohistochemical features of prostate cancer]. Svit medytsyny ta biolohii. 2016; 4(58): 113-115. (Ukrainian).
3. Masood A, lqbal N, Shohab D, Hasan A, Aimon S, Mahmood U, et al. Clinicopathological characteristics of prostate cancer in patients presenting to a tertiary care private sector hospital. Journal of the College of Physicians and Surgeons Pakistan. 2018; 28 (5): 40911.

4. Kandasamy S, Pothen L, Letha V, Sankar S, Priya PV, Varghese $\mathrm{S}$. Diagnostic utility of AMACR in prostatic carcinoma. Journal of Evolution of Medical and Dental Sciences. 2017; 6: 2869-73.

5. Hryhorenko VM, Danylets RO, Vikarchuk MV. Biomarkery rannoi ta dyferentsiinoi diahnostyky raku peredmikhurovoi zalozy [Biomarkers of early and differential diagnosis of prostate cancer]. Klinichna khirurhiia. 2017; 1: 43-48. (Ukrainian).

6. Ali AR, Hayam ER, Kateb MI, El, Soheir S. Evaluation of minima prostate cancer in needle biopsy specimens using AMACR (P504S), p63 and Ki67. Life Science Journal. 2012; 9; 12-21.

7. Rathod SG, Jaiswal DG, Bindu RS. Diagnostic utility of triple antibody (AMACR, HMWCK and P63) stain in prostate neoplasm. Journal of family medicine and primary care. 2019; 8(8): 2651-5.

8. Bahrii MM, Dibrova VA, Popadynets $\mathrm{OH}$. Metodyky morfolohichnykh doslidzhen [Methods of morphological studies] Vinnytsia: Nova knyha; 2016. 328 s. (Ukrainian).

9. Shepitko VI, Vilkhova OV, Sohuiko YuR. Strukturna orhanizatsiia peredmikhurovoi zalozy [Structural organization of the prostate]. Visnyk problem biolohii ta medytsyny. 2015; 4 (125): 59-62. (Ukrainian).

10. Korzhevskyi DE, Hyliarov AV. Osnovy hystolohycheskoi tekhnyky [Basics of histological technique]. Sankt-Peterburh: SpetsLyt; 2010. 95 s. (Russian)

11. Sherstiuk OA, Ustenko RL, Pyliuhyn AV, Svyntsytskaia NL. Stereomorfolohycheskye osobennosty stroenyia prostaty cheloveka y slozhnosty ee nomenklatury [Stereomorphological features of the structure of the human prostate and the complexity of its nomenclature]. Halytskyi likarskyi visnyk. 2015; 22 (3): 1114. (Russian).

12. Jain D, Gupta S, Marwah N, Kalra R, Gupta V, Gill M, et al Evaluation of role ofalpha-methyl acyl-coenzyme A Evaluation of role ofalpha-methyl acyl-coenzyme A
racemase/P504S and high molecular weight cytokeratin in racemase/P504S and high molecular weight cytokeratin
diagnosing prostatic lesions. J Can Res Ther. 2017;13:21-5.

13. Brius P, Brius $Э$. Praktycheskaia statystyka dlia spetsyalystov Data Science [Practical statistics for professionals Data Science] Sankt-Peterburh: BKhV-Peterburh; 2018. 304 s. (Russian).

14. Vtorushin SV, Bezgodova NV, Pleshkunov AA. Molecular biological factors of prediction of prostate cancer. Siberian Journal of Oncology. 2017; 16 (1): 82-90.

15. Kovaleva OV, Samoilova DV, Shitova MS, Oleinikova NA, Danilova NV, Malkov PG et al. A Novel Monoclonal Antibody Against Alphe-Methylocilo Against Alpha-Methylacyl-CoA Racemase Applicable for ParaffinEmbedded Tissues and Diagnostics of Prostate Cancer. 2016. Monoclonal Antibodies in Immunodiagnosis and Immunotherapy Vol. 36, No. 1 https://doi.org/10.1089/mab.2016.0048

16. Rathod SG, Jaiswal DG, Bindu RS. Diagnostic utility of triple antibody (AMACR, HMWCK and P63) stain in prostate neoplasm. $J$ Family Med Prim Care. 2019 Aug; 8(8): 2651-2655.

\section{Рефpeoat}

\section{НЕКОТОРЫЕ МОРФОЛОГИЧЕСКИЕ ПРОГНОСТИЧЕСКИЕ КРИТЕРИИ РАКА ПРЕДСТАТЕЛЬНОЙ ЖЕЛЕЗЫ}

Мед В.В., Бабенко В.И., Филенко Б.

Ключевые слова: рак предстательной железы, атипизм, шкала Глиссона, AMACR, прогноз.

Наиболее распространенной гистологической формой рака предстательной железы является ацинарная аденокарцинома различной степени дифференцировки. Основным диагностическим критерием, который учитывается при выборе метода лечения рака предстательной железы, является морфологический атипизм желез, который отображается в шкале Глиссона, а также степень экспрессии иммуногистохимических маркеров, одним из которых является альфа-метилацил-КоА-рацемазы. Однако, остается полностью непонятной зависимость выраженности экспрессии р504S от степени градации опухоли по системе Глиссона. Целью исследования было определение взаимосвязи между степенью дифференцировки аденокарциномы предстательной железы по шкале Глиссона и степенью экспрессии ИГХ маркера p504s. Было исследовано биопсийный материал получен от 37 пациентов с раком предстательной железы. По шкале Глиссона материал разделили на три группы: первая отвечала оценке 1-4 балла, вторая - 5-7 баллов и третья - 8-10 баллов. ИГХ исследования по определению экспрессии антигена p504s проводили с помощью моноклональных анти-AMACR/P504s. Aнализ зависимости между степенью дифференцировки аденокарциномы предстательной железы по шкале Глиссона и степенью экспрессии ИГХ маркера p504s, было обнаружено четкую закономерность и установлено наличие сильного корреляционной связи ( $r=0,69)$ между данными морфологическим характеристикам опухоли. Обнаруженная нами закономерность говорит о специфичности данного маркера при злокачественных опухолевых процессах в предстательной железе, что согласуется с данными других исследований, и позволяет более точно дифференцировать стадийность процесса по шкале Глиссона. Это в определенной степени дает основание для выбора адекватных методов лечения пациентов и усовершенствовать прогностические критерии. 


\section{Summary}

ON SOME MORPHOLOGICAL PROGNOSTIC CRITERIA FOR PROSTATE CANCER

Med V.V., Babenko V.I., Filenko B.M.

Key words: prostate cancer, atypism, Gleason grading scale, AMACR, prognosis.

Acinar adenocarcinoma of varying degrees of differentiation is considered the most common histological form of prostate cancer. The major diagnostic criterion to be considered when choosing a method of treatment for prostate cancer is the morphological atypism of the glands, which is reflected in the Gleason grading scale, as well as the degree of expression of immunohistochemical markers, one of which is alphamethylacyl-CoA racemase. However, the dependence of the expression of p504S on the degree of tumour grading by the Gleason grading system is not fully understood to date. The paper was aimed at establishing a relationship between the degree of differentiation of prostatic adenocarcinoma according to the Gleason grading scale and the degree of expression of the p504s IGC marker. Biopsy material obtained from 37 patients with prostate cancer was examined. According to the Gleason grading scale, the material was divided into three groups: 1-4 scores for the first group, 5-7 scores for the second group and 8-10 scores for the third group. IGC studies on determination of the p504s antigen expression were performed using monoclonal anti-AMACR/P504s. The analysis of the relationship between the degree of differentiation of the prostatic adenocarcinoma according to the Gleason scoring and the degree of expression of p504s IGC marker revealed a clear pattern and demonstrated a strong correlation $(r=0,69)$ between these morphological characteristics of the tumour. The revealed pattern indicates the specificity of this marker in malignant tumour processes in the prostate gland, which is consistent with other studies, and enables to make more accurate differentiation of the tumour staging according to the Gleason grading scale. To a certain extent, this provides a basis for the selection of adequate methods of the treatment and for the improvement of prognostic criteria.

DOI 10.31718/2077-1096.20.2.189

УДК: 616.315/.311:599.323.4

Хілініч Є.С., Давиденко В.Ю.

\section{СТРУКТУРНА ОРГАНІЗАЦІЯ ЗАЛОЗИСТОЇ ЗОНИ СЛИЗОВОЇ ОБОЛОНКИ ТВЕРДОГО ПІДНЕБІННЯ ІНТАКТНИХ БІЛИХ ЩУРІВ}

Українська медична стоматологічна академія, м. Полтава

Дослідження деяких авторів свідчать про те, що морфологія, гістохімія і іннервація слизової оболонки у щурів має багато схожості з людиною. Як показує практика, більшість експериментальних досліджень із вивчення впливу тих чи інших фракторів на організм людини, проводяться на тваринах, особливо на щурах. В попередніх власних дослідженнях ми використовували щурів для експерименту, тому для вивчення впливу мономеру акрилової пластмаси на слинні залози обрали щурів для подальшої екстраполяції даних про морфологічні особливості малих слинних залоз цих тварин і людини. Мета дослідження - вивчити структурну організацію залозистої зони слизової оболонки твердого піднебіння білих інтактних щурів з подальшою екстраполяцією даних на організм людини. Для досягнення поставленої мети проводили експериментальні дослідження на лабораторних статевозрілих щурах лінії Вістар віком від 1 до 1,5 року. Вивчення мікропрепаратів поперечних зрізів твердого піднебіння білих шурів за допомогою світлового мікроскопа при малих збільшеннях дозволило виявити в його структурі слизову оболонку і добре розвинену підслизову основу з великою кількістю малих слинних залоз. Проведені морфологічні дослідження структурної організації слизової оболонки твердого піднебіння інтактних білих щурів засвідчили схожість будови малих слинних залоз щурів і людини, що підтверджує правильний вибір експериментальних тварин та в подальшому дозволяє екстраполювати отримані дані.

Ключові слова: слизова оболонка, тверде піднебіння щурів, малі слинні залози, структурна організація

Дана робота є фрагментом НДР «Вплив стоматологічних конструкцій й матеріалів на протезне ложе та адаптаційні можливості організму», № державної реєстрації $0116 U 004188$.

\section{Вступ}

Найбільш важливим чинником для повноцінного балансу гомеостазу порожнини рота $є$ слина, яку продукують слинні залози. Представляє вона собою біологічно активну рідину, яка виконує ряд важливих функцій: травну, за рахунок участі у перетравленні їжі, бактеріцидну, за рахунок очищення і захисту зубів та слизової оболонки від бактеріальних та хімічних подразників
$[1,2]$. За даними літературних джерел, майже 30\% всієї слини виділяють малі слинні залози [3, 41.

Дослідження деяких авторів [8] свідчать про те, що морфологія, гістохімія і іннервація слизової оболонки у щурів має багато схожості з людиною. Як показує практика, більшість експериментальних досліджень із вивчення впливу тих чи інших фракторів на організм людини, проводяться на тваринах, особливо на щурах. 